\title{
An Indicator-Based Framework to Evaluate Sustainability of Farming Systems: Review of Applications in Tuscany
}

\author{
Cesare Pacini $^{1 *}$, Giulio Lazzerini ${ }^{1}$, Paola Migliorini ${ }^{1}$, Concetta Vazzana ${ }^{1}$ \\ ${ }^{1}$ Diparetimento di Scienze Agronomiche e Gestione del Territorio Agro-Forestale, Università di Firenze \\ Piazzale delle Cascine 18, 50144 Firenze, Italy
}

Received: 3 December 2008. Accepted: 13 March 2009.

\begin{abstract}
Agricultural researchers widely recognise the importance of sustainable agricultural production systems and the need to develop appropriate methods to measure sustainability at the farm level. Policymakers need accounting and evaluation tools to be able to assess the potential of sustainable production practices and to provide appropriate agro-environmental policy measures. Farmers are in search of sustainable management tools to cope with regulations and enhance efficiency. This study proposes an indicator-based framework to evaluate sustainability of farming systems. Main features of the indicators' framework are the relevance given to different spatial scales (farm, site and field), production and pedo-climatic factors, and a holistic view of the agro-ecosystem. The framework has been conceived to tackle different purposes ranging from detailed scientific analyses to farm-level management systems and cross-compliance. Agro-environmental indicators can be calculated, simulated with models or directly measured with different levels of detail proportionally to the aims of the evaluation exercise. The framework is organised in a number of environmental and production systems and sub-systems. For each system environmental critical points are identified with corresponding agro-environmental indicators and processing methods. A review of applications of the framework in Tuscany, Italy, since 1991 is presented. Applications range from prototyping farming systems, to integrated farm ecological-economic modelling, comparisons between organic, integrated and conventional farming systems, farm eco-management voluntary audit schemes and cross-compliance. Strengths and weaknesses of the framework are discussed against generic requirements of information systems and operational issues.
\end{abstract}

Key-words: Indicator-based framework, farming systems, organic agriculture, conventional agriculture, integrated agriculture, sustainability evaluation, agro-environmental information systems.

\section{Introduction}

Agricultural researchers widely recognise the importance of sustainable agricultural production systems and the need to develop appropriate methods to measure sustainability at the farm level. Policymakers need accounting and evaluation tools to be able to assess the potential of sustainable production practices and to provide appropriate agro-environmental policy measures. Farmers are in search of sustainable management tools to cope with regulations and enhance efficiency. Indicators are often used to measure sustainability performances on different spatial scales; they can be strongly ecologi- cal in focus and very detailed, or they are policy oriented. So, indicators are developed that differ greatly in information content and condensation of this information (Braat, 1991). In order to guide decision-makers in taking choices coherent with the sustainability principles, indicators can be embedded in a logical sequence of phases, often called "framework".

There is currently a vast range of indicatorbased frameworks to evaluate sustainability of farming systems and land-use in the literature. Some focus on environmental impact (see, for an example, the critical review of 12 indicatorbased methods reported by Van der Werf and

* Corresponding Author: Tel.: +39 055 3288252; Fax: +39 055 332472. E-mail address: gaiocesare.pacini@unifi.it 
Petit, 2002), others hold a stronger holistic component and consider socio-economic aspects as well. Examples of frameworks of the latter type broadly applied in the agricultural sector are the International Framework for Evaluating Sustainable Land Management (FESLM, Smith and Dumanski, 1994), the framework of the Research Network on Integrated and Ecological Arable Farming Systems for EU and Associated Countries (Vereijken, 1999), the Checklist for Sustainable Landscape Management (Van Mansvelt and Van der Lubbe, 1999), the Problem-Solving Framework for Modelling Sustainability Issues (Weersink et al., 2002) and the Framework for Assessing the Sustainability of Natural Resource Management Systems (MESMIS, López-Ridaura et al., 2002).

In general, frameworks differ on multiple features such as their theoretical background, hierarchical level, temporal dimensions of sustainability, geographical extent of application and evaluation procedures. Most of the mentioned frameworks are based on Systems Theory, while the checklist for sustainable landscape management relies on the Maslow's theory of human motivations (Maslow, 1968). The advantage of the Maslow's theory, as adapted by Van Mansvelt and Van der Lubbe (1999) to sustainable land management, is that it allows a direct translation of human motivations to sustainability objectives. The sequence of human needs from the Maslow's triangle is used to find a common ground in the overwhelming range of values and criteria for sustainable land-use and landscape management. These needs range from sheer survival, to social integration and cultural development. As stressed by the authors these points are largely in line with the requirements phrased by the UN's Food and Agricultural Organisation (FAO) for its policy toward Sustainable Agricultural and Rural Development (SARD, 1991) and the agricultural chapter of Agenda 21 as adopted at the United Nations Conference on Environment and Development (UNCED) held in Rio de Janerio, Brazil, 3 to 14 June 1992. Food security, employment, income generation, people's participation and human development are clearly addressed. Compliant with the Maslow's theory, the checklist is organised according to the three major realms of science: the (a)biotic, socio-economic and psycho-cultural realms. This organi- sation merges well with the principles of the Capital Theory applied to sustainable development (Stern, 1997; Daly, 1994; Daly and Costanza, 1992).

The framework developed by Vereijken includes a clear and straightforward procedure to define short- and long-term sustainability objectives and weights at the farming system level. Objectives are then linked to parameters (indicators) and farming practices and inserted in a coherent, effective, operational procedure, which includes criteria and targets/thresholds. The Vereijken's and the Van Mansvelt and Van der Lubbe's frameworks seem to hold similarities; however, the emphasis of the evaluation exercises under the latter is on checking the state of sustainability of a given landscape, while the main aim of the Vereijken's framework is to advise decision-makers on sustainable development of their farming systems (e.g., Rossi and Nota, 2000, and Kabourakis, 1996, respectively).

The MESMIS evaluation framework comprises a clear definition of the object under evaluation (including the socio-environmental context, and prevailing and alternative management systems), the identification of critical points, the identification, measurement and monitoring of diagnostic indicators, the phase of presentation of results as well as one dealing with conclusions and recommendations. MESMIS is based on a systems approach and on the following concepts: a) to be effective, interdisciplinary analysis has to produce insights that significantly transcend those of the individual participating disciplines (Conway, 1987; Garcia, 1992); and b) in Systems Theory certain principles stand for all systems regardless of the hierarchical level considered (Conway, 1987; Odum, 1994).

In MESMIS, a set of central system attributes (or properties) of sustainable natural resource management systems are identified that hold across disciplines or scales to keep both the evaluation of sustainability and the derivation of indicators theoretically consistent.

The FESLM is designed to embrace different sustainability problems throughout diverse regions in the world. This makes the framework flexible. According to the FESLM Working Party (Dumanski et al., 1991), the five objectives of sustainable land management (i.e. productivity, security, environmental protection, economic viability and social acceptability) are seen to be 
the basic "pillars" on which sustainable land management must be constructed and against which its findings must be tested and monitored. In general, this framework presents similarities with MESMIS, whose structure partly originates from FESLM; however, in MESMIS the single steps of the evaluation procedure are delineated with more detail.

The strength of the framework of Weersink et al. (2002) lies in the fact that it is effectively problem-oriented and gives a comprehensive picture of possible modelling approaches, including multiple objectives/indicators, different analysis units and risk. On the other hand a procedure of identification of objectives, criteria and indicators is not given by the Weersink framework.

In general, the above-mentioned frameworks hold strong conceptual backgrounds and complex organisations of the evaluation protocols; however, due to either sometime cryptic theoretical superstructures or to a narrow range of application purposes, their direct practical applicability to ordinary farms or to vast ranges of farm types and evaluation purposes is questionable; more effort is needed to optimise the balance between conceptual soundness and operantionalability. Besides, indicator used often lack of reference to different hierarchical spatial levels and do not consider pedo-climatic variability.

This paper proposes an indicator-based framework to evaluate sustainability of farming systems. The framework takes the shape of a holistically designed information system to support decisions at different levels in the agricultural sector and is named Agro-Environmental Sustainability Information System (AESIS). The AESIS (current formulation of the framework) and its previous version (the EAIS, environmental accounting information system; Pacini et al., 2000) have been developed from previous experiences dating since 1991 (Pileri, 1992; Vazzana et al., 1997; Vereijken, 1999), aiming at finding the right balance between a range of different application purposes and the level of complexity of indicators, including different spatial scales, production and pedo-climatic factors. During this time span the framework has been developed incorporating new elements retrieved also from other studies (including those above-mentioned).
Although the AESIS focuses on the environmental and production dimensions of sustainability, links with the socio-economic dimensions are considered as well. In fact, database consistency with the European Farm Accountancy Data Network (FADN) as well as integrated patterns of result interpretation were tested and validated in a number of case-studies.

In the following section generic requirements of Environmental Information Systems (EIS) are presented, in Section 3 the AESIS is described, which is discussed in Section 4 against generic EIS requirements and indications given by other frameworks and studies in the literature; in the last section conclusions are drawn together with recommendation for future research.

\section{Requirements of environmental information systems}

Effective and efficient management decisions depend on reliable information. This is true for environmental matters as well as for every other field of management action. Until recently, environmental monitoring played only a minor role compared to economic monitoring. According to Azzone and Mazzini (1994), in order to support external and internal communication, an EIS must: 1) point out the real "environmental results", 2) present these results with reference to the specific physical conditions and production and pollution processes involved, and 3) express the relation between agricultural activities and environmental results. These general guidelines point to several problems that must be faced when designing an EIS: a) environmental impacts are diverse, b) many stakeholders are involved (farmers, policymakers et cetera), all with their own requests for information, c) differences in physical conditions can have large impacts, d) the information should yield a correct measurement of environmental-economic trade-offs, e) there is a need for a systems approach.

Environmental impacts change depending on physical conditions and human activities of a given area. An EIS aimed at supporting decisions at different levels in the field of sustainability for the agricultural sector needs to be flexible enough to accommodate this diversity in a cost-efficient way. 
Currently, the most important requests for environmental information come from policymakers, farmers and advisory services. Consequently, an EIS should be applicable for at least three different purposes: a) by the policymakers, as an instrument to monitor at regional level the environmental effects of agri-environmental measures and to audit at farm level the compliance of the single farms with legislative standards; b) by the farmers, as an instrument to audit the efficiency of the environmental investments and of the agri-environmental farming practices in order to better meet the standards requested either by the Government or by private organisations (organic agriculture certifying associations, large retail organisations and co-operatives that develop green labels, etc.); c) by advisory agencies, as a data and analytical base for the technical assistance to farmers.

Differences in physical conditions and in the type of production system can have large impacts on environmental management and have to be taken into account. This is important for farmers but even more so when the information from the system is used in policy design or evaluation. Policy decisions have to be based on data acceptable to the individuals who face the outcomes of these decisions.

To enable a direct link between production on the farm and environmental results, the environmental data have to be collected in such a way that they can be related to the data gathered in the regular economic farm accounting systems (e.g., the EU FADN) and/or in the more technically oriented data management systems (e.g., organic agriculture registers, refuse registers).

Taking decisions in the field of agroecosystem management can give cause for conflicts between different environmental aims (e.g., soil erosion vs. impact due to herbicide use). To avoid these conflicts and achieve high levels of efficiency of management, decision-makers need comprehensive evaluation tools and information systems that can consider all farm results integrally and simultaneously.

\section{Description of the framework}

\subsection{System boundaries}

According to Hannon (1991) "an ecological accounting system is a framework in which the quantified connections between organisms (individual species, collections of species) and their abiotic environment can be placed and balanced, without ambiguity, omission or double counting exchanges, at any scale which an investigator chooses". In order to identify such an information system, we need (a) to delimitate the agro-ecosystem under study in space and time, and (b) to choose a set of processes with their input and output products. The AESIS is aimed to measure environmental externalities produced by agro-ecosystems and to connect them with the farm economic accounting. Hence, the spatial boundaries of the present accounting system coincide with those of the administrative and cadastral farm boundaries and the temporal limits are determined by the standard one-year period in financial accountancy. The farm spatial unit is divided in smaller subunits, i.e. sites and fields ${ }^{1}$ in order to consider the within-farm spatial heterogeneity of pedoclimatic factors and production activities.

\subsection{AESIS general structure}

Main features of the indicator framework are the relevance given to different spatial scales (farm, site and field), production and pedo-climatic factors (Fig. 1), and a holistic view of the agro-ecosystem.

The framework has been conceived to tackle different purposes ranging from detailed scientific analyses to farm-level management systems and policy monitoring. Besides, the framework has been designed and tested to be coherent with the current European financial accounting model (FADN).

The AESIS has been developed from previous experiences dating since 1991 (Pileri, 1992; Vazzana et al., 1997; Vereijken, 1999), aiming at finding the right balance between a range of different application purposes and the level of complexity of indicators. Agro-environmental indicators can be calculated, simulated with

\footnotetext{
${ }^{1}$ Under the AESIS framework a site is defined as a farm spatial sub-unit having relatively homogeneous landforms, soil types, water table and climate. A field is defined as an undivided sub-unit of a site with homogeneous land use (e.g., crop, ecological infrastructure, etc.); in this context undivided means that the field is not interrupted by any permanent structure such as streets, permanent surface ditches of the water system or hedge-rows.
} 


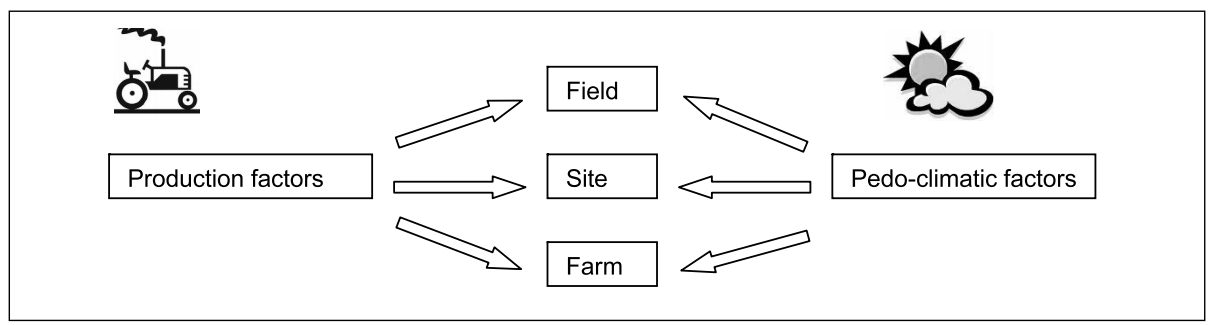

Figure 1. Spatial references and descriptive factors of the indicators' framework. models or directly measured with different levels of detail, proportionally to the aims of the evaluation exercise. Given the above-mentioned layout of the system based on ecological concepts, the procedural steps to apply the framework are reported in Figure 2, so as they were modified from Weersink et al. (2002), and explained in the following sections.

\subsection{Framework procedure: define the sustain- ability issues}

Being a framework oriented to a problem-solving approach, the AESIS application procedure starts with gathering of information already available on the issues related to sustainability. Following, specific environmental critical points that connect issues with the farm agroecosystem are pinpointed. The information system was organised into several environmental and production systems and subsystems; within each module a number of environmental and production processes take place, which affect the relevant critical points (Tab. 1).

The performance of the management of each environmental and production process in the agro-ecosystem is quantified by a set of agroenvironmental indicators. In order to integrate environmental aspects with financial accounting for subsequent integrated evaluation of environmental and socio-economic dimensions, indicators relevant to each environmental and production module were separated into two categories: 1) stock indicators, describing the state of the farm environmental capital, and b) flow indicators, which concern annual changes of environmental capital and, therefore, represent both positive externalities or asset appreciations (i.e. production of environmental services) and negative externalities or asset depreciations (i.e. chemical input pollution, soil erosion et cetera) caused by farm production cycles.

In this way an analogy between the AESIS
DEFINE THE SUSTAINABILITY ISSUES

- identify issues related to environmental sustainability

- identify detailed environmental critical points and connect them to farm environmental and production systems

- choose indicators

SOLUTIONS TO THE SUSTAINABILITY ISSUES

- settle a comparison layout (e.g., comparisons between farms, comparisons of different management systems/ techniques on the same farm, comparisons of farms with thresholds, comparisons between farm model simulation results)

- identify indicator thresholds (or critical limits, sustainability targets)

- define alternative management systems (e.g., organic, integrated, environmentally-friendly, best available technologies etc.)

- identify policy measures

EVALUATING SOLUTION ALTERNATIVES

- select calculation methods of indicators proportional to the evaluation purpose

- integrate indicators in a farm simulation model

- measure indicators

- present results

Figure 2. AESIS procedural steps (modified from Weersink et al., 2002).

and the balance sheet and the income statement in financial accountancy can be made. For each environmental and production process an environmental balance sheet and an environmental profit-loss account can be produced. In the environmental balance sheet, assets are measured by stock indicators. This balance sheet is assessed once a year in correspondence with the financial one. Changes between two balance assessments are reported in the environmental profit-loss account and coincide with the flows of the environmental capital during the year. Changes in the profit-loss account are measured by flow indicators and correspond to depreciations (costs) or appreciations (revenues) of the assets.

In practice, depending on data availability and methods used, it is not always possible to 
Table 1. General structure of the AESIS.

\begin{tabular}{|c|c|c|c|}
\hline Environmental critical point & Subsystem & System & System type \\
\hline $\begin{array}{l}\text { Water quality } \\
\text { Water demand, water-table level } \\
\text { Flood risk, water stagnation, } \\
\text { landscape conservation }\end{array}$ & $\begin{array}{l}\text { Water quality } \\
\text { Water balance } \\
\text { Drainage system }\end{array}$ & Water & $\begin{array}{l}\text { Stock and flow } \\
\text { system }\end{array}$ \\
\hline $\begin{array}{l}\text { Soil erosion } \\
\text { Soil salinization, loss of organic matter }\end{array}$ & $\begin{array}{l}\text { Soil morphology and structure } \\
\text { Soil chemical components }\end{array}$ & Soil & \\
\hline $\begin{array}{l}\text { Crop biotic stress, agro-ecological } \\
\text { identity of fields, Landscape diversity } \\
\text { Livestock biodiversity, Livestock } \\
\text { intensity } \\
\text { Refuse }\end{array}$ & $\begin{array}{l}\text { Plant production } \\
\text { Cattle production } \\
\text { Refuse management }\end{array}$ & $\begin{array}{l}\text { Production } \\
\text { activities }\end{array}$ & \\
\hline Biodiversity & $\begin{array}{l}\text { Flora } \\
\text { Fauna }\end{array}$ & Flora and fauna & \\
\hline Nitrogen cycle & $\begin{array}{l}\text { Nitrogen balance at farm level } \\
\text { Nitrogen balance at herd level } \\
\text { Nitrogen balance at soil level }\end{array}$ & $\begin{array}{l}\text { Nitrogen } \\
\text { balance }\end{array}$ & Flow system \\
\hline Phosphorus cycle & $\begin{array}{l}\text { Phosphorus balance at farm level } \\
\text { Phosphorus balance at herd level } \\
\text { Phosphorus balance at soil level }\end{array}$ & $\begin{array}{l}\text { Phosphorus } \\
\text { balance }\end{array}$ & \\
\hline Biocide pollution & Crop protection & & \\
\hline Non-replaceable energy demand & Energy & & \\
\hline
\end{tabular}

calculate both stock and flow indicators for each environmental and production process. Flow indicators can be calculated directly, summing all appreciations and depreciations, and/or as a change between two balance assessments of two consecutive years. On the other hand, it is not possible to make an indirect computation of a stock indicator starting from a flow indicator.

\subsection{Framework procedure: solutions to the sus- tainability issues}

The AESIS has been conceived not only to asses the sustainability of real-life farms but also to evaluate possible production alternatives in order to improve the environmental performances of production processes. The first step of this process consists in designing a comparison layout where current practices under evaluation are compared with different management systems or techniques (between and/or within-farm, based on experiment or model results), with scientifically-determined sustainability thresholds, management targets and politically-determined critical limits. Such thresholds (or targets, or limits) are identified for each single indicator. They are part of the solution to the sustainability problem to the extent deci- sion-makers change their strategies in order to move towards the goals they represent.

Following, alternative management systems indicated in the comparison layout (e.g., organic, integrated, environmentally-friendly production methods, best available technologies, etc.) are defined together with policy measure to promote them (the latter applies only to simulation modelling).

\subsection{Framework procedure: evaluating solution al- ternatives}

In this phase of the evaluation procedure the calculation methods of the indicators are selected following a criterion of proportionality to the evaluation purpose; e.g. indicator processing methods for policy auditing have to be applied to a huge number of farms and might be based on simple presence/absence observations, while the measurement of indicators for research and policy planning are calculated for selected representative farms by applying complex simulation models.

In Table 2 a list of AESIS case study applications in Tuscany is represented. In Table 3 a list of indicators with purpose-specific processing procedures from data to indicators is re- 
Table 2. Main features of the case study applications, showing location, type, duration and corresponding references.

\begin{tabular}{|c|c|c|c|c|}
\hline Case & Location & Type of application & Duration & Reference \\
\hline 1 & $\begin{array}{l}\text { San Casciano, } \\
\text { Florence }\end{array}$ & $\begin{array}{l}\text { Long-term experiment on the } \\
\text { Montepaldi station to prototype organic } \\
\text { and integrated arable micro-farms }\end{array}$ & $1991-2000$ & $\begin{array}{l}\text { Vazzana et al., } 1997 \\
\text { Vereijken, } 1999\end{array}$ \\
\hline 2 & $\begin{array}{l}\text { Borgo San } \\
\text { Lorenzo, Florence }\end{array}$ & $\begin{array}{l}\text { Model-based evaluation of organic } \\
\text { and conventional FSs on an ordinary } \\
\text { dairy farm }\end{array}$ & 1995 & $\begin{array}{l}\text { Pacini et al., } 1998 \\
\text { Omodei-Zorini and Pacini, } 1998 \\
\text { Omodei-Zorini and Pacini, } 2004\end{array}$ \\
\hline 3 & Mugello, Florence & $\begin{array}{l}\text { Evaluation of organic, integrated and } \\
\text { conventional FSs on ordinary dairy farms }\end{array}$ & $1995-1996$ & Migliorini et al., 2000 \\
\hline 4 & $\begin{array}{l}\text { Mugello (Florence), } \\
\text { Migliarino-San } \\
\text { Rossore-Massa- } \\
\text { ciuccoli Regional } \\
\text { Park (Pisa and } \\
\text { Lucca), Maremma } \\
\text { Regional Park } \\
\text { (Grosseto) }\end{array}$ & $\begin{array}{l}\text { Model-based analyses to compare organic, } \\
\text { integrated and conventional FSs of } \\
\text { dairy, arable and mixed cattle-arable } \\
\text { farm types and to support decisions for } \\
\text { multi-objective policy-making }\end{array}$ & $1998-2000$ & $\begin{array}{l}\text { Pacini et al., } 1999 \\
\text { Pacini et al., 2002a } \\
\text { Pacini et al., 2002b } \\
\text { Pacini et al., 2003a } \\
\text { Pacini et al., 2003b } \\
\text { Pacini et al., 2004b } \\
\text { Pacini et al., 2004c }\end{array}$ \\
\hline 5 & $\begin{array}{l}\text { San Casciano, } \\
\text { Florence }\end{array}$ & $\begin{array}{l}\text { Long-term experiment on the Montepaldi } \\
\text { station to prototype arable micro-farms } \\
\text { and compare organic and conventional } \\
\text { farming systems }\end{array}$ & 2001-now & $\begin{array}{l}\text { Vazzana et al., } 2008 \\
\text { Migliorini and Vazzana, } 2007 \\
\text { Migliorini and Vazzana, 2006b } \\
\text { Migliorini, 2006a }\end{array}$ \\
\hline 6 & Val d'Orcia, Siena & $\begin{array}{l}\text { Detailed analysis on the effects of three } \\
\text { different organic and conventional FSs } \\
\text { on the planned and associated biodiversity }\end{array}$ & 2001-2004 & Vazzana and Lazzerini, 2007 \\
\hline 7 & Valdelsa, Florence & $\begin{array}{l}\text { Indicator-based environmental review } \\
\text { for EMSs of vine-olive organic, integrated } \\
\text { and conventional agri-touristic farms }\end{array}$ & 2004-2005 & $\begin{array}{l}\text { Pacini and Giannini, 2004a } \\
\text { Pacini et al., } 2005\end{array}$ \\
\hline 8 & Val d'Orcia, Siena & $\begin{array}{l}\text { Effects of different field margins on some } \\
\text { biodiversity components (plant species } \\
\text { and carabid beetles) of four farms }\end{array}$ & 2004-2005 & Lazzerini et al., 2007a \\
\hline 9 & Tuscany Region & $\begin{array}{l}\text { Application of multi-purpose audit } \\
\text { schemes: cross-compliance audit systems } \\
\text { and EMSs to ten arable, dairy and } \\
\text { olive FSs }\end{array}$ & 2004-2006 & Omodei-Zorini et al., 2006 \\
\hline 10 & $\begin{array}{l}\text { Ornamental Nursery } \\
\text { Rural District, Pistoia }\end{array}$ & $\begin{array}{l}\text { Implementation of EMSs to two } \\
\text { ornamental nurseries }\end{array}$ & 2006 & Lazzerini et al., 2007b \\
\hline 11 & Mugello, Florence & $\begin{array}{l}\text { Model-based sustainability impact } \\
\text { assessment of climate change on organic } \\
\text { and conventional dairy FSs }\end{array}$ & 2007 & Moriondo et al., 2007 \\
\hline
\end{tabular}

Legend: FS, farming system; EMS, environmental management system.

ported. All of the calculation procedures reported in Table 3 have been tested in a number of different case-studies as reported on the top of Columns 3, 4 and 5 of Table 2, including data availability and cost of data collection. Data sources are farm accounting systems, interviews with farmers, regional public organisations, bibliographical sources, farm nutrient accounting systems, farm maps, observations in field, chemical analyses. Each farm is divided into sites and fields, and different data are collected for each of them.

The stock/flow classification in Table 1 is determined by the indicator procedures. If one of the AESIS methods is applied to measure an environmental asset, then its outcome will be a stock indicator. If it is not possible to measure the environmental asset at a specific moment in time, then only its changes over time will be measured and the method applied will produce a flow indicator.

Finally, indicators are measured and results are presented. This last part is particularly important as the evaluation exercise is meaningless if the beneficiaries of the information on the evaluation do not gain a clear idea of the results of the exercise and the implications on their decisions. A number of options are possible to show results; however, as discussed in the next section, trade-off curves and spider diagrams are the most common in AESIS studies. 
Table 3. Indicator calculation procedures as related to environmental critical points and type of AESIS application purpose.

\begin{tabular}{lllll}
\hline Critical point & Indicator & & Indicator procedure & \\
\hline & & $\begin{array}{l}\text { Modelling approach } \\
\text { Case-studies 2, 4, 11 } \\
\text { (Table 2) }\end{array}$ & $\begin{array}{l}\text { Experimental station } \\
\text { Case-studies 1, 5 } \\
\text { (Table 2) }\end{array}$ & $\begin{array}{l}\text { Ordinary farms } \\
\text { Case-studies 3, 6, 7, 8, } \\
\text { (Table 2) }\end{array}$ \\
\hline $\begin{array}{l}\text { Water quality } \\
\text { Water demand, } \\
\text { water-table level }\end{array}$ & Water balance & GLEAMS $^{1}\left(\mathrm{Fi}, \mathrm{P} \& \mathrm{P}^{1}\right)$ & $\begin{array}{l}\text { Water use with farm } \\
\text { records (Fa, Pr) }\end{array}$ & $\begin{array}{l}\text { Water use with farm } \\
\text { records (Fa, Pr) }\end{array}$ \\
$\begin{array}{l}\text { Flood risk, water } \\
\text { stagnation, }\end{array}$ & $\begin{array}{l}\text { Drainage system } \\
\text { length }\end{array}$ & $\begin{array}{l}\text { In-field observations } \\
\text { (Fi, P\&P) }\end{array}$ & $\begin{array}{l}\text { In-field observations } \\
\text { (Fi, P\&P) }\end{array}$ & $\begin{array}{l}\text { In-field observations } \\
\text { (Fi, P\&P) }\end{array}$
\end{tabular}

landscape

conservation

Terrace length

Soil erosion

Soil erosion

In-field observations (Fi, P\&P)
GLEAMS (Fi, P\&P)

Soil quality

Loss of organic matter

Soil salinity Heavy metals

Chemical analyses (S, Pe)

Soil organic matter content

Chemical analyses (S, Pe)

Agro-ecological

Field size

identity of fields

Field max width/length ratio

Rotation years

Landscape diversity Crop diversity

$\begin{array}{ll}\begin{array}{l}\text { Livestock } \\ \text { biodiversity } \\ \text { Livestock intensity }\end{array} & \begin{array}{l}\text { Livestock } \\ \text { biodiversity } \\ \text { Livestock load } \\ \text { Manure managemen }\end{array} \\ \text { Refuse } & \begin{array}{l}\text { Dangerous waste } \\ \text { load } \\ \text { Percent of recycling } \\ \text { waste }\end{array} \\ \begin{array}{l}\text { Associated } \\ \text { biodiversity } \\ \text { of flora }\end{array} & \begin{array}{l}\text { biodiversity and } \\ \text { richness }\end{array}\end{array}$

of flora

Biodiversity of fauna

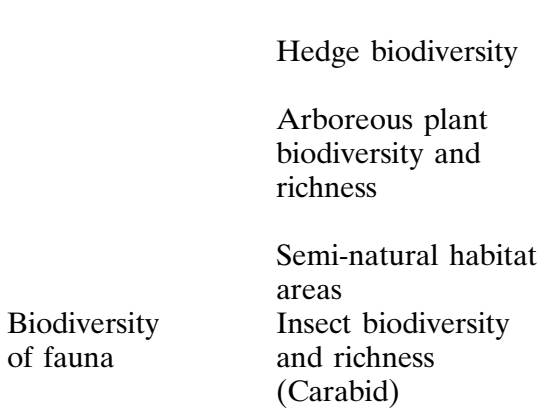

In-field observations (Fi, P\&P)

In-field observations

(Fi, P\&P)

Farm records, In-field observations (Fa, P\&P) Modified Shannon index and Daget and Poissonet $^{2}$ (S, Pr)

Farm records $(\mathrm{Fa}, \mathrm{Pr})$

Farm records (Fa, Pr)

Balance (Fa, Pr)

Modified Braun-

Blanquet method ${ }^{3}$;

Shannon and Weaver;

Species Richness

(Fi, P\&P)

In-field observations

(Fi, P\&P)

Map and in-field o

bservations and

Shannon and Weaver

(Fi, Pr)

Farm records, In-field

Shannon and Weaver; Shannon and Weaver;

Species Richness

(Fi, P\&P)

Map and In-field

Map and In-field

Farm records, In-field Map and In-field

Modified Braun-

Blanquet method;

Shannon and Weaver; Species Richness (Fi, P\&P)

In-field observations (Fi, P\&P)

Map and in-field observation Shannon and Weaver (Fi, Pr) Species Richness (Fi, P\&P)
Soil cover index during year and critic period (Fi, Pr)

Yearly monitoring with chemical analyses (Fi, Pe) Organic matter balance with farm records (Fa, Pr) observations (Fi, P\&P) observations (Fi, P\&P) observations (Fa, P\&P) observations (Fi, P\&P)

Potential risk of soil erosion (S, P\&P)

Chemical analyses (S, Pe)

Organic matter balance with farm records (Fa, Pr)

Chemical analyses (Fa, Pe)

Map and In-field observations (Fi, P\&P) Map and In-field observations (Fi, P\&P)

Farm records, In-field observations (Fa, P\&P) Map and in-field observations on field adjacency and density (Fi, Pr)

Farm records (Fa, Pr)

Farm records (Fa, Pr) Liquid manure load (Fa, Pr)

Farm records (Fa, Pr)

Farm records (Fa, Pr)

Farm records on number of species (Fa, Pe)

In-field observations (Fi, P\&P) Map and in-field o bservations (Fi, Pr)

Farm records, In-field observations (Fa, P\&P) 
(continued from p. 30)

Table 3. Indicator calculation procedures as related to environmental critical points and type of AESIS application purpose.

\begin{tabular}{|c|c|c|c|c|}
\hline Critical point & Indicator & & Indicator procedure & \\
\hline & & $\begin{array}{l}\text { Modelling approach } \\
\text { Case-studies 2, 4, } 11 \\
\text { (Table 2) }\end{array}$ & $\begin{array}{l}\text { Experimental station } \\
\text { Case-studies } 1,5 \\
\text { (Table 2) }\end{array}$ & $\begin{array}{l}\text { Ordinary farms } \\
\text { Case-studies } 3,6,7,8 \text {, } \\
9,10 \text { (Table 2) }\end{array}$ \\
\hline Nitrogen cycle & Nitrogen leaching & GLEAMS (Fi, P\&P) & $\begin{array}{l}\text { Nitrogen balance with } \\
\text { farm records }(\mathrm{Fa}, \mathrm{Pr})\end{array}$ & $\begin{array}{l}\text { Nitrogen balance with } \\
\text { farm records }(\mathrm{Fa}, \mathrm{Pr})\end{array}$ \\
\hline & Nitrogen run-off & GLEAMS (Fi, P\&P) & $\begin{array}{l}\text { Nitrogen balance with } \\
\text { farm records }(\mathrm{Fa}, \mathrm{Pr})\end{array}$ & $\begin{array}{l}\text { Nitrogen balance with } \\
\text { farm records }(\mathrm{Fa}, \mathrm{Pr})\end{array}$ \\
\hline & Soil Nitrates & & $\begin{array}{l}\text { Yearly monitoring with } \\
\text { chemical analyses } \\
(\mathrm{Fi}, \mathrm{Pr})\end{array}$ & \\
\hline & $\begin{array}{l}\text { Ammonium } \\
\text { emissions }\end{array}$ & GLEAMS (Fa, P\&P) & & Farm records $(\mathrm{Fa}, \mathrm{Pr})$ \\
\hline Phosphorous cycle & Phosphorus sediment & GLEAMS (Fi, P\&P) & $\begin{array}{l}\text { Phosphorus balance } \\
\text { with farm records } \\
(\mathrm{Fa}, \mathrm{Pr})\end{array}$ & $\begin{array}{l}\text { Phosphorus balance } \\
\text { with farm records } \\
(\mathrm{Fa}, \mathrm{Pr})\end{array}$ \\
\hline & Soil phosphates & & $\begin{array}{l}\text { Yearly monitoring } \\
\text { with chemical analyses } \\
(\mathrm{Fi}, \mathrm{Pr})\end{array}$ & \\
\hline Biocide pollution & $\begin{array}{l}\text { Environmental } \\
\text { potential risks of } \\
\text { pesticide use }\end{array}$ & $\mathrm{EPRIP}^{4}(\mathrm{Fi}, \mathrm{P} \& \mathrm{P})$ & GUS $^{5}(\mathrm{Fi}, \mathrm{Pr})$ & $\mathrm{LQ}^{6}$ index $(\mathrm{Fi}, \mathrm{Pr})$ \\
\hline Energy demand & Energy balance & Farm records $(\mathrm{Fi}, \mathrm{Pr})$ & Farm records $(\mathrm{Fi}, \mathrm{Pr})$ & Farm records $(\mathrm{Fi}, \mathrm{Pr})$ \\
\hline
\end{tabular}

Legend: Fi, field; S, site; Fa, farm; P\&P, production and pedo-climatic factors; Pr, production factor; Pe, pedo-climatic factor.

1 "Groundwater Loading Effects of Agricultural Management Systems" model (Knisel, 1993).

${ }^{2}$ The linear method from Daget and Poissonet (1971) is one of the methods used for the analysis of biodiversity; it foresees the identification of measurement points every $20 \mathrm{~m}$ along a transect of plant cover and the calculation of the Shannon index of diversity for each point.

${ }^{3}$ The Braun-Blanquet method (Cappelletti, 1976; Arrigoni et al., 1985) is a commonly used census method that assesses vascular plants biodiversity by estimating the cover percentages of species and their distribution in the parcel observed. In the AESIS applications only species cover was taken into account.

${ }^{4}$ The Environmental Potential Risk Indicator for Pesticides (EPRIP) is based on comparison of predicted environmental concentration (PEC), estimated including pedo-climatic factors at a very local scale (field and surroundings), with toxicological parameters, and is obtained from an integrated classification system of 9 different environmental indices; it evaluates potential hazard for soil, groundwater by leaching, surface water by drift and run-off, air by volatilization (Trevisan et al., 1999).

${ }^{5}$ The Groundwater Ubiquity Score (GUS) is an index of pesticide leachability based on the time of degradation of pesticide in the soil and its molecular solubility in water; if GUS is $>2,8$ the pesticide is leachable; if GUS $<1,8$ the pesticide is not leachable; if $2,8>$ GUS $>1,8$ the pesticide is considered moderately leachable (Gustafson, 1989).

${ }^{6}$ Leached Quantity is a contamination potential index to assess aquifer vulnerability (Trevisan et al., 1993).

\section{Review of applications}

Application purposes range from detailed, model-based scenario analyses, policy planning, comparisons between organic, integrated and conventional farming systems, analyses based on field experiments, prototyping farming systems, analyses for decision support to ordinary organic and environmentally-friendly farms, ecomanagement voluntary audit schemes.

\subsection{Case-studies}

In Table 2 the list of case-study applications of the AESIS is reported. Case-study farms include small, medium and large enterprises, as well as experimental stations, and range from arable to mixed cattle-arable, dairy, vineyard, olive, vegetable, fruit and ornamental plant nursery production. Pedo-climatic conditions of case-studies under survey, although belonging to the same Region, range from pre-mountain climates with a mean annual rainfall of $1000 \mathrm{~mm}$ (Mugello, northern Tuscany) to dry Mediterranean climates with a mean annual rainfall of $625 \mathrm{~mm}$ (Maremma, southern Tuscany), including a number of different soil types. In compliance with EIS requirement a, such a broad range of tests allowed to calibrate the AESIS in order to cope with diversity of agro-environmental impacts. 


\subsection{Discussion on the framework procedure: de-} fine the sustainability issues

The definition of the sustainability issues in most of the case-studies started from information retrieved from the annual Tuscany Region reports on the state of the environment. In such reports information on environmental critical points is also supplied by means of a set of landscape indicators. Given such availability of data, there has not been the need to structure the corresponding AESIS phases; however, extending the use of the AESIS to other regions of Europe and the World would require to structure them in a more detailed way.

Instead, in past applications the focus was on enforcing within the AESIS a holistic view of the agro-ecosystem (EIS requirement e). Hannon (1991) stressed the importance in ecosystem accounting of measuring the material, energy and service trade-offs between all the ecological processes of a given ecosystem. Disregarding such aspects of accounting can also give cause for conflicts between different government programmes or regulations as far as the environmental aims are concerned (Hammond and Goodwin, 1997; Callens and Tyteca, 1999). A holistic perspective was therefore enforced in the AESIS by linking the critical points to a number of farm environmental and production systems and subsystems (Tab. 1), which were simultaneously and integrally monitored in casestudies. Besides, the combination of the stock and flow structure of environmental and production systems together with the FADN-consistent boundaries of the AESIS allowed to integrate AESIS outcomes with results of financial accounting systems (EIS requirement d). A comparative study (Certoma and Migliorini, 2007) carried out in Tuscany to investigate the potential of the AESIS and the MESMIS framework (Lopez-Ridaura et al., 2002) revealed that the holistic approach in AESIS, based on the logical chain critical point-environmental system-indicator, is more concrete and understandable by stake-holders than the criticalpoint-attribute-diagnostic indicator paradigm of MESMIS. This is in line with what stressed by Speelman et al. (2007), who state that the description of attributes in MESMIS is somewhat vague and difficult to conceptualise and difficult to link to concrete indicators.
4.3 Discussion on the framework procedure: solutions to the sustainability issues

The AESIS framework has been developed with the ambition to be operational and concrete, so to be applicable to a range of different purposes in a cost-efficient way. This means that the holistic/systems approach has been translated in a pragmatic sequence of steps. Solutions to the sustainability problems are investigated starting by settling a comparison layout. This might exclude some options from the range of possible solutions of the problem but allows for a straightforward decision path towards implementation of sustainability. In the different casestudies comparisons between farms, comparisons of different management systems/techniques on the same farm, comparisons of farms with thresholds, comparisons between farm model simulation results were carried out and gave valuable advice on practical issues. As advised also by Weersink et al. (2002), indicators thresholds (or critical limits, sustainability targets), alternative management systems (e.g., organic, integrated, environmentally-friendly, best available technologies etc.) and policy measures were specified in detail and connected to realworld practices in order to strengthen the operationalability of the method; an example of such an approach is given by Pacini (2003a, pp. 146-157, 30 and 88-90, respectively).

\subsection{Discussion on the framework procedure: evaluating solution alternatives}

A central role in the implementation of the AESIS is held by the identification of calculation procedures of the indicators. A considerable number of procedures has been tested in almost two decades of research and connected according to the proportionality principle of the EU (for a definition of the principle reference is made to $\mathrm{Eu}$ ropean Commission, 2005) to specific purposes of application. For all these procedures scientific reliability, data availability and cost-efficiency were tested in relevant case-studies.

Table 3 shows indicators procedures grouped according to three different purposes of application of the AESIS: 1) detailed model-based analyses for evaluation of organic, integrated and conventional farming systems (OFS, IFS and CFS, respectively) and for policy planning (Column 3);2) application to micro-farms on an 
Table 4. Technical, environmental and financial results of the conventional and organic versions of a model simulating the impacts of EU policy scenarios on organic and conventional agriculture at farm level (Pacini et al., 2004c).

\begin{tabular}{|c|c|c|c|c|c|}
\hline \multirow{2}{*}{$\begin{array}{l}\text { FS }^{1} \\
\text { Agenda } 2000 / \text { scenario }\end{array}$} & \multicolumn{2}{|c|}{$\mathrm{CFS}^{2}$} & \multicolumn{2}{|r|}{$\mathrm{OFS}^{3}$} & \multirow[b]{2}{*}{$\begin{array}{l}\text { No EU } \\
\text { support }\end{array}$} \\
\hline & $\begin{array}{l}\text { Agenda } \\
2000\end{array}$ & $\begin{array}{l}\text { No EU } \\
\text { support }\end{array}$ & $\begin{array}{l}\text { Agenda } \\
2000\end{array}$ & $\begin{array}{l}\text { Only organic } \\
\text { EU support }\end{array}$ & \\
\hline Cattle (n. of dairy cows) & 150 & 139 & 150 & 150 & 151 \\
\hline \multicolumn{6}{|l|}{ Crops (ha) } \\
\hline Barley & 8.3 & 11.7 & 33.8 & 35.7 & 36.7 \\
\hline Broad bean & - & - & 16.9 & 17.8 & 18.3 \\
\hline Maize for silage & 8.3 & 11.7 & 11.3 & 12.2 & 12.7 \\
\hline Maize for silage - irrigated & 0.0 & 0.0 & 5.6 & 5.6 & 5.6 \\
\hline Maize for grain & 5.7 & 0.0 & - & - & - \\
\hline Maize for grain - irrigated & 45.0 & 13.8 & 0.0 & 0.0 & 0.0 \\
\hline Grassland & 26.2 & 39.4 & 74.9 & 77.3 & 77.0 \\
\hline Alfalfa & 44.5 & 64.7 & 5.4 & 4.4 & 2.7 \\
\hline Italian ryegrass & 8.3 & 11.7 & - & - & - \\
\hline Set-aside (ha) & 6.7 & 0.0 & 5.1 & 0.0 & 0.0 \\
\hline Green spaces (ha) & 34.3 & 34.3 & 34.3 & 34.3 & 34.3 \\
\hline Total (ha) & 187.3 & 187.3 & 187.3 & 187.3 & 187.3 \\
\hline \multicolumn{6}{|l|}{ Environmental indicators } \\
\hline Nitrogen leaching (kg/ha) & 26.1 & 21.6 & 6.0 & 5.7 & 5.6 \\
\hline Nitrogen runoff (kg/ha) & 9.5 & 5.7 & 1.9 & 2.0 & 2.0 \\
\hline Soil erosion $(\mathrm{t} / \mathrm{ha})$ & 2.2 & 1.5 & 4.5 & 4.7 & 5.0 \\
\hline Ground water balance $\left(\mathrm{m}^{3} / \mathrm{ha}\right)$ & -92.1 & -33.0 & -2.1 & -3.3 & -3.1 \\
\hline Surface water balance $\left(\mathrm{m}^{3} / \mathrm{ha}\right)$ & -73.1 & -8.2 & +18.7 & +19.5 & +20.4 \\
\hline Environmental potential pesticide risks (score/ha) & 40 & 20 & 0 & 0 & 0 \\
\hline Herbaceous Plant Biodiversity (score/ha) & 59 & 67 & 83 & 82 & 82 \\
\hline Hedge length (m/ha) & 0 & 0 & 0 & 0 & 0 \\
\hline Surface drainage system length $(\mathrm{m} / \mathrm{ha})$ & 55 & 0 & 40 & 0 & 0 \\
\hline Manure surplus (t) & 0 & 541 & 252 & 176 & 145 \\
\hline Slurry surplus (t) & 7 & 0 & 817 & 767 & 792 \\
\hline \multicolumn{6}{|l|}{ Revenues (€/ha) } \\
\hline Cattle products (milk, sale of heifers and bull calves) & 2150 & 1446 & 2453 & 1777 & 1788 \\
\hline Maize grain sale & 138 & 36 & 0 & 0 & 0 \\
\hline EU CMOs ${ }^{4}$ ' support payments for crops & 168 & 0 & 114 & 0 & 0 \\
\hline EU Organic method support payments & 0 & 0 & 280 & 289 & 0 \\
\hline Total & 2456 & 1482 & 2847 & 2066 & 1788 \\
\hline \multicolumn{6}{|l|}{ Variable costs $(€ / h a)$} \\
\hline Seasonal labour & 130 & 66 & 47 & 47 & 49 \\
\hline Concentrates & 106 & 19 & 219 & 188 & 192 \\
\hline Fertilizers and pesticides & 76 & 50 & 0 & 0 & 0 \\
\hline Ecological infrastructures & 14 & 0 & 10 & 0 & 0 \\
\hline Other costs & 348 & 230 & 279 & 283 & 285 \\
\hline Total & 674 & 365 & 555 & 518 & 526 \\
\hline Gross margin $(€ / h a)$ & 1782 & 1117 & 2292 & 1548 & 1222 \\
\hline
\end{tabular}

${ }^{1}$ Farming system.

${ }^{2}$ Conventional farming system.

${ }^{3}$ Organic farming system.

${ }^{4}$ European Union common market organizations.

long term experimental station to prototype organic arable FSs and to compare organic and conventional farming practices (Column 4); 3) application to ordinary farms for the development of farm environmental management systems (EMS) and for evaluating organic, integrated and conventional FSs (Column 5). There is not space in this manuscript to describe each procedure in detail; the detailed description and/or bibliographical reference of the indicator procedures with relevant discussion are reported in the articles quoted in the right-hand side column of Table 2 .

Although of course a number of nuances occur between these three groups, in general terms each of them corresponds to the needs of rele- 


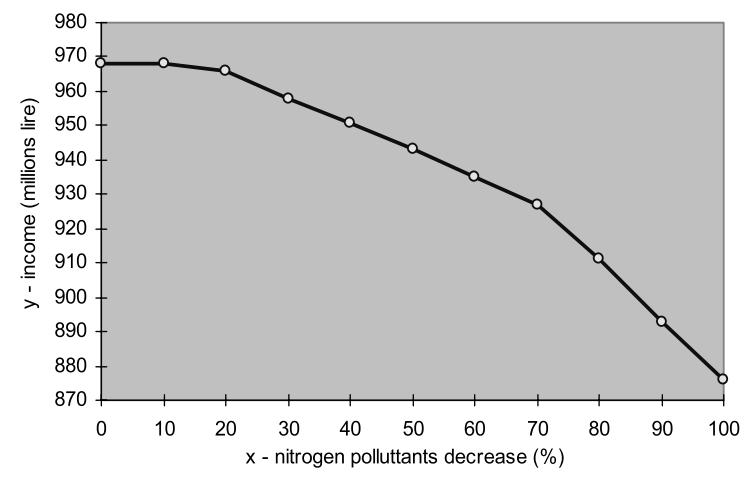

Figure 3. Tradeoff curve showing the relationship between ecological and economic objectives (modified from Pacini et al., 1998).

vant groups of end-users, i.e. policy-makers, technicians and farmers (EIS requirement b). The balance between data detail including pedo-climatic factors and operational costs of the survey was modulated according to the purpose of the application (e.g., analyses extended to high number of farms required simpler and less expensive procedures). To make a practical example with pesticide indicators, in some studies it was decided to use the Environmental Potential Risk Indicator for Pesticides (EPRIP, Trevisan et al., 1999), other were carried out with the GUS (Groundwater Ubiquity Score) method (Gustafson, 1989). While EPRIP can evaluate potential hazard for soil, groundwater by leaching, surface water by drift and run-off, air by volatilization, GUS supplies information on leaching but disregards drift, run-off and volatilization. However, the calculation requirements of GUS are considerably inferior to those of EPRIP, whose data needs include detailed information on the active ingredients, soil, climate, drainage system and crop production techniques.

Hierarchical spatial levels of indicators ranged from field, to site and farm level. The more detailed was the spatial level (Field vs. site and farm), the higher the processing procedure requirements were, and the more the EIS requirement $\mathrm{c}$ was fulfilled. In general, the highest level of data requirements were those of the indicators for model-based research and policy planning (Tab. 3, Column 3), followed by those for analyses on experimental station (Column 4), and experimental farms (Column 5). Data requirements on production factors were similar for all the
Figure 4. Cluster analysis (CA) of plant richness and diversity species in field margins of four farms in Siena Province (year 2005) (Lazzerini and Vazzana, 2007a). Legend: cluster 1 involves plots with field margins represented by sown grass strips and wild strips of Selvoli farm (farm in conversion, Pienza), Costantini farm (organic, Castiglione d'orcia) and Rimbecca farm (organic, Castiglione d'Orcia); cluster 2 involves plots with field margins represented by cultivated strips of Crespi farm (conventional, Castioglione d'Orcia).

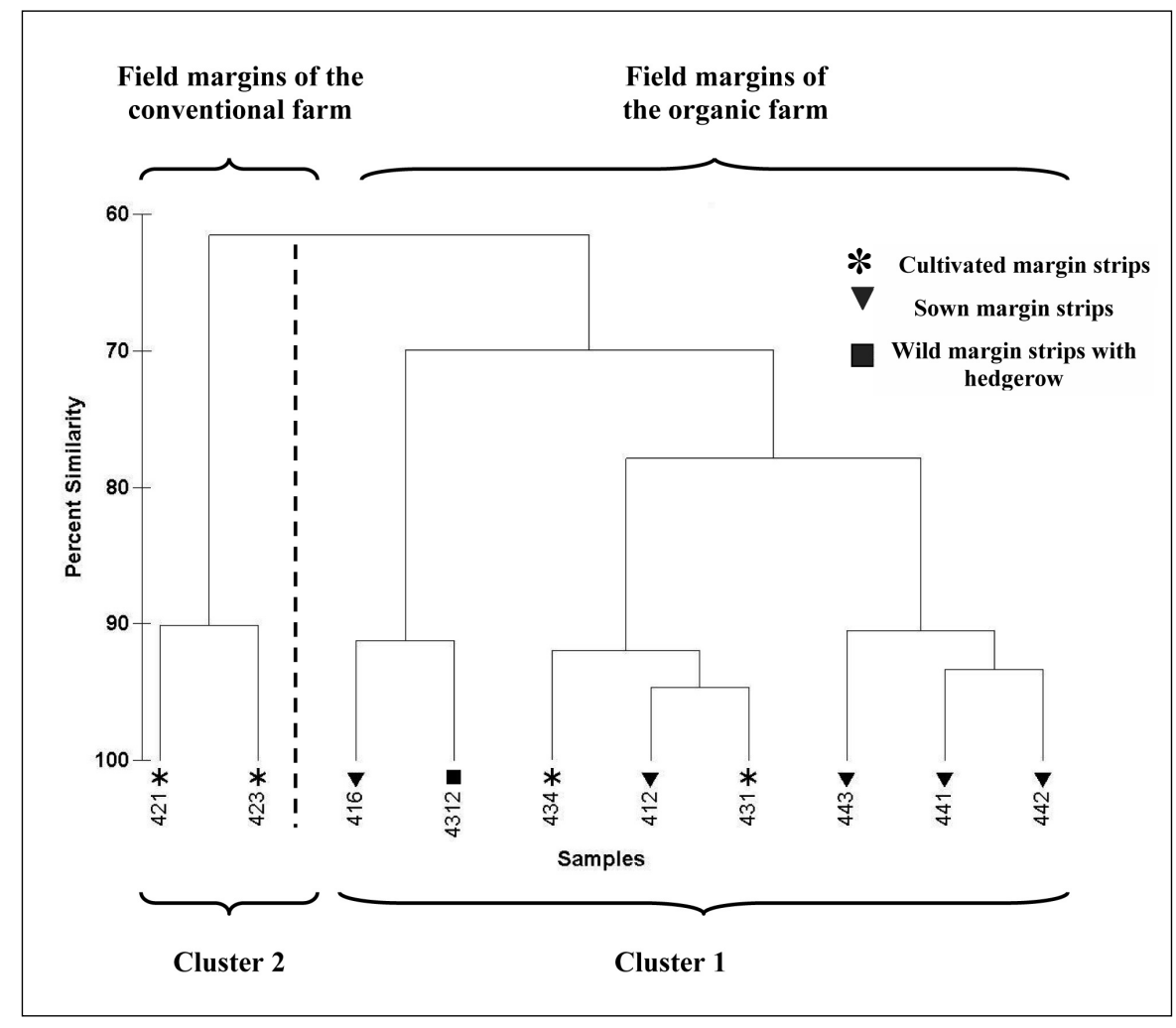




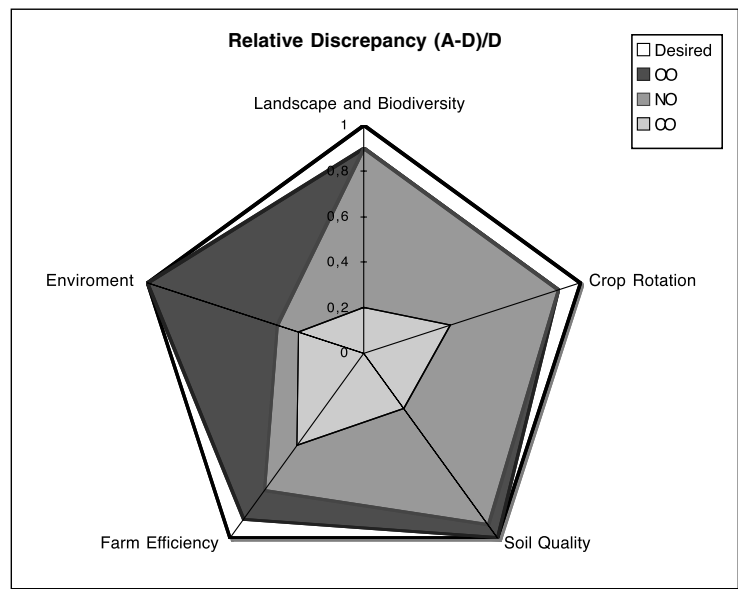

Figure 5. Sustainability and Agro-ecological Indicators results used to evaluate environmental and management system: Relative discrepancy of achieved (A) to desired (D) results in the experimental Old Organic (OO), New Organic (NO) and Conventional (CO) agro-ecosystems of Montepaldi farm (Tuscany) as average of 2003/2005 (modified from Migliorini, 2006a). A larger area corresponds to fewer discrepancies and, thus, to more desired value results.

groups of processing procedures (Columns 3 to 5 ), while data on pedo-climatic factors were collected mainly for detailed analyses (Columns 3 and 4). In some case-studies indicator calculation procedures were integrated in farm simulation models in order to take simultaneously into account production and pedo-climatic factors for policy analyses (Tab. 3, Column 3, see Tab. 4 for a practical example of models' outputs).

Presentation of results under the AESIS framework can take different shapes according to the end-user requirements and types of purpose of the analysis. Three commonly applied presentation methods are trade-off curves, statistical multi-variate analysis graphs and spider (or amoeba) diagrams. Trade-off curves were used to communicate model results for multiobjective policy-making (see for an example Fig. $3)$. This is in line with what found in the literature. Antle et al. (1998) argue that plotting environmental indicators (in physical terms) against economical indicators (in monetary terms) for alternative production systems is a preferred method for presenting information on sustainability problems to policy-makers. In detailed analyses on biodiversity multi-variate analysis graphs (see for an example Fig. 4) were used to present the results of indicators at field level of the farms under study in order to get

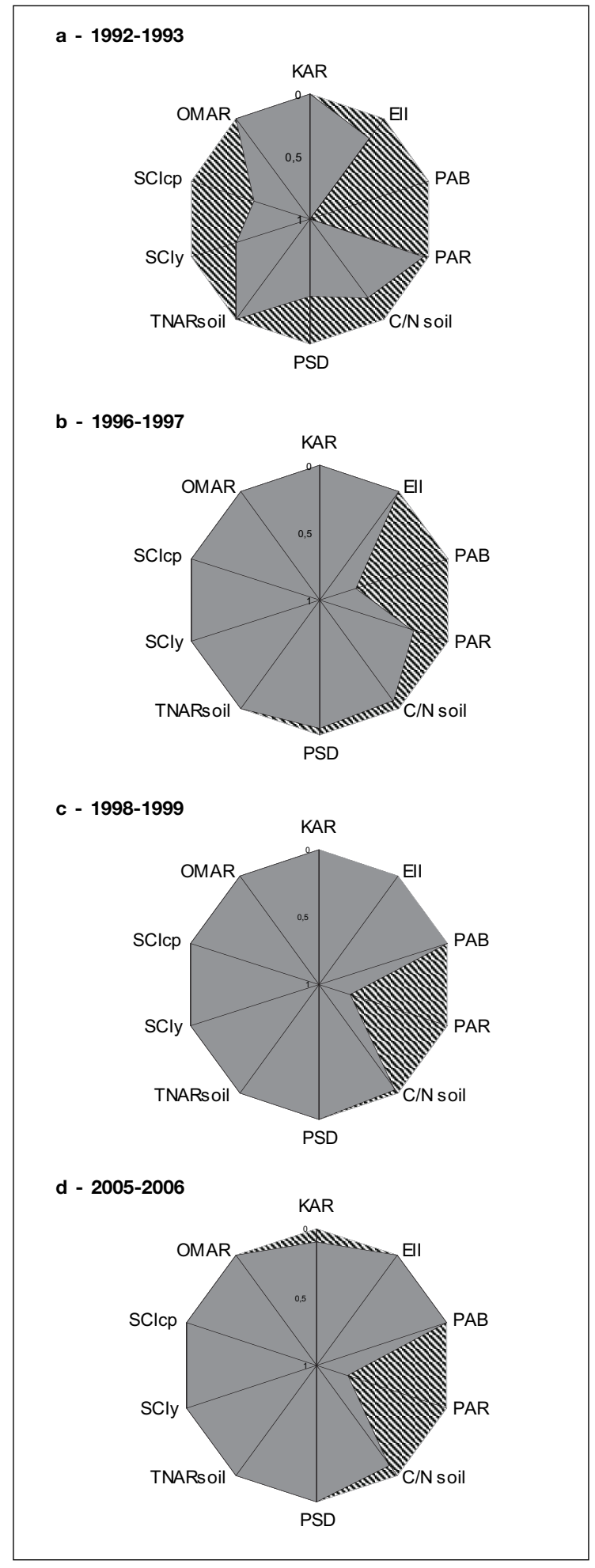

Figure 6. Evaluation of the development in time of the sustainability impact in the organic long term experimental farm of Montepaldi (Tuscany): at starting point (a-1992-03), after four (b-1996-97), six (c-1998-99) and thirteen (d-200506) years since conversion (Vazzana et al., 2008). 
insight on the relationships between pedo-climatic conditions and biodiversity. Spider diagrams were used in some analyses to evaluate the level of sustainability of different agroecosystems, both in space and in time (Fig. 5 and 6 , respectively).

\section{Conclusions}

Different versions of the framework were applied with case-specific sets of indicators and calculation procedures to a large range of hierarchical spatial levels, production systems and methods, farm sizes, basic and applied research purposes. The framework proved to be flexible and effective in grounding the sustainability concept in the reality of farming systems. Specific features of the framework are that it is holistically designed, pedo-climatic factors are included, it can be integrated with FADN databases, it is multi-purpose in the sense that proved to be able to cope with information needs of different end-users' groups (policy-makers, technicians and farmers).

The AESIS has been mostly applied in Tuscany. In order to extend the scope of application of AESIS and strengthen its theoretical bases, additional research efforts have been recently initiated to device a theoretical model for the identification of sustainability issues based on concept analysis (Merante and Pacini, 2008; Sartori, 1984), and to develop and test a procedure of multi-variate analysis to identify farm typologies for sustainability evaluation based on local data and expert knowledge (Pacini et al., 2006; Righi et al., 2009). Further research has focused on indicator aggregation methods (Paracchini et al., 2008; Paracchini et al., 2009) and farmer strategies through multi-criteria decision analysis and modelling (Pacini et al., 2008) but needs to be better fitted into the AESIS scheme.

\section{Acknowledgements}

The authors would like to acknowledge Dr. J.C.J. Groot for his helpful comments on an earlier version of the present manuscript. Research for this publication was carried out as part of the Specific Targeted Research Project SVAPPAS (Sustainable Value Analysis of Policy and Performance in the Agricultural Sector), funded under the EU $6^{\text {th }}$ Framework Programme for Research, Technological Development and Demonstration (European Commission, DG Research, contract N. SSPE-CT-
2006-44215). The content of the paper does not represent the official position of the European Commission and is entirely under the responsibility of the authors.

\section{References}

Antle J.M., Capalbo S.M., Crissman C.C. 1998. Tradeoffs in policy analysis: conceptual foundations and disciplinary integration. In: Crissman C.C., Antle J.M., Capalbo S.M. (eds.): Economic, environmental and health tradeoffs in agriculture: pesticides and the sustainability of Andean potato production, 21-40. Kluwer Academic Publishers, Boston, UK.

Arrigoni P.V., Nardi E., Raffaelli M. 1985. La vegetazione del parco naturale della Maremma (toscana). Dipartimento di Biologia Vegetale dell'Università di Firenze, Italy.

Azzone G., Manzini R. 1994. Measuring strategic environmental performance. Business Strategy and the Environment, 3, 1:1-14.

Braat L. 1991. The predictive meaning of sustainability indicators. In: Kuik O., Verbruggen H. (eds.): In search of indicators of sustainable development. Kluwer Academic Pub., Dordrecht (NL).

Callens I., Tyteca D. 1999. Towards indicators of sustainable development for firms. A productive efficiency perspective. Ecological Economics, 28:41-53.

Cappelletti C. 1976. Trattato di botanica. Utet, Torino, Italy.

Certoma C., Migliorini P. 2007. The MESMIS approach to evaluate sustainability of organic farms in Tuscany. The International Conference "Environment: Survival and Sustainability", 19-24 February, Near East University, Northern Cyprus.

Conway G.R. 1987. The properties of agroecosystems. Agricultural Systems, 24:95-117.

Daget P., Poissonet J. 1971. Une méthode d'analyse phytologique des prairies. Annales Agronomiques, 22:5-41.

Daly H. 1994. Operationalizing sustainable development by investing in natural capital. In: Jansson A.M., Hammer M., Folke C., Costanza R.: Investing in natural capital: the ecological economics approach to sustainability. Island Press, Washington, DC (USA), 22-37.

Daly H., Costanza R. 1992. Natural capital and sustainable capital. Conservation Biology, 6:37-46.

Dumanski J., Eswaran H., Pushparajah E., Smyth A. (eds.) 1991. Evaluation for sustainable land management in the developing world. Vol. 1: Towards the development of an international framework. IBSRAM Proceedings 12, Vol. 1.

European Commission, 2005. Impact assessment guidelines. SEC791.

Garcia R. 1992. Interdisciplinariedad y sistemas complejos. In: Leff E. (ed.): Ciencias sociales y formación ambiental, 85-123. Gedisa-UNAM-UNESCO, Mexico.

Gustafson D.I. 1989. Groundwater Ubiquity Score: A Simple Method For Assessing Pesticide Leachability. Environmental Toxicology and Chemistry, 8:339-357. 
Hammond C., Goodwin B. 1997. An Ex-Post Evaluation of the Conservation Reserve Program: Participation, Erosion, and Interaction with Related Programs. Paper presented at the 1997 AAEA Meeting in Toronto, Canada.

Hannon B. 1991. Accounting in Ecological Systems. In: Constanza R. (ed.). Ecological Economics: the Science and Management of Sustainability, 234-252. Columbia University Press, New York, USA.

Kabourakis E. 1996. Prototyping and dissemination of ecological olive production system: A methodology for designing and a first step towards validation and dissemination of prototype ecological olive production systems (EOPS) in Crete. PhD thesis Wageningen Agricultural University, Wageningen, The Netherlands.

Knisel G. 1993. GLEAMS Groundwater Loading Effects of Agricultural Management Systems - Version 2.10. University of Georgia-Coastal Plain Experiment Station-Biological and Agricultural Engineering Department Publication No. 5, Tifton, Georgia, USA, 259 p.

Lazzerini G. 2001. Paragrafi 2.1-2, 3.1-2, 4.2.2-3, 5.3.2, 6.13-4, 4.1 con Rovai M. In: Buiatti M., Cecchi R., Brunori D., Franchini D., Omodei-Zorini L., Saba R., Spugnoli P., Vazzana C., Androni L., Lazzerini G., Pacini G.C., Rovai M., Bellini L., Cecchi B., Sacchetti P., Giannini A., Belli B., Calistri L., Failoni M., Rossi G. 2001. Contabilità ambientale in agricoltura Toscana. Il Sole 24 Ore Spa, Roma, Italia, 82 p.

Lazzerini G., Camera A., Benedettelli S., Vazzana C. 2007a. The role of field margins in agro-biodiversity management at the farm level. Italian Journal of Agronomy, 2:127-134.

Lazzerini G., Merante P., Pacini G.C., Vazzana C. 2007b. I sistemi di gestione ambientale: il caso di studio del settore vivaistico a Pistoia. Rivista scientifica di orticoltura, floricoltura e frutticoltura, 14, 2.

Lopez-Ridaura S., Masera O., Astier M. 2002. Evaluating sustainability of complex socio-environmental systems: the MESMIS Framework. Ecological indicators, 2:135-148.

Maslow A.H. 1968. Motivation and personality. Harper and Row, New York, USA, 411 p.

Merante P., Pacini C. 2008. Report on the state-of-the-art of sustainability approaches in agriculture. Sixth EU Framework Programme for Research and Technological Development, SVAPPAS Project, Deliverable 1.1.

Migliorini P., Vazzana C., Raso E., Martini A. 2000. The role of soil fertility in sustainable agriculture: simulation of diverse management cases in Mugello area (Tuscany). International Scientific Conference of IFOAM, 27-31 August, Basel, Switzerland.

Migliorini P. 2006a. Sustainability evaluation of organic farming systems in Tuscany. PhD thesis, University of Florence, Italy.

Migliorini P., Vazzana C. 2006b. Evaluation of sustainability: results from a long term experimental arable systems in Tuscany. "What will organic farming deliver?". Colloquium of Organic Researchers (COR2006), 18-20 September 2006, Edinburgh Conference Centre, Heriot-Watt University, Edinburgh, Scotland, UK.
Migliorini P., Vazzana C. 2007. Biodiversity indicators for sustainability evaluation of conventional and organic agro-ecosystems. Italian Journal of Agronomy, 2, 2.

Moriondo M., Pacini C., Bindi M., Vazzana C. 2007. Sustainability of agricultural production systems in a changing climate. In: Proceedings Farming Systems Design 2007. An International Symposium on Methodologies on Integrated Analysis on Farm Production Systems, September 10-12, Catania, Sicily, Italy.

Odum H.T. 1994. Ecological and General Systems: An Introduction to Systems Ecology. University Press of Colorado, USA, 644 p..

Omodei-Zorini L., Pacini C. 1998. Environmental economics: an application of optimisation models at farm level. In: Proceedings $7^{\text {th }}$ ICCTA - International Congress for Computer Technology in Agriculture, November 15-18, Florence, Italy.

Omodei Zorini L., Pacini C. 2004. La valutazione dell'agricoltura biologica: un modello aziendale economico-ambientale. Aestimum, 44:25-47.

Omodei Zorini L., Lazzerini G., Vazzana G., Brunori G., Gorelli S., Rovai M., Lombardi G., Casini L. 2006. Rapporto di ricerca "Sistemi informativi e comunicazione per politiche agro-ambientali". ARSIA, Florence, Italy.

Pacini C., Vazzana C., Omodei Zorini L. 1998. A farm economic-environmental approach applied to the evaluation of sustainability: the model of an organic dairy farm. In: Brossier J., Dent B. (eds.): Gestion des exploitations et des ressources rurales. Entreprendre, négocier, évaluer. Farm and rural management. New context, new constraints, new opportunities. Etud. Rech. Syst. Agraires Dév., 31:191-204.

Pacini C., Lazzerini G., Omodei-Zorini L., Brunori G., Rovai M., Vazzana C. 1999. Environmental accounting in agriculture. In: Stolton S., Geier B., McNeely J.A. (eds.): The relationship between nature conservation, biodiversity and organic agriculture, 184-196. IFOAM, Germany.

Pacini C., Wossink A., Vazzana C., Omodei-Zorini L. 2000. Environmental accounting in agriculture: a theoretical overview with special reference to Tuscany. In: Proceedings Meeting of the American Agricultural Economics Association, July 30 - August 2. Tampa, Florida (USA). Available at <http://agecon.lib.umn.edu/ aaea00/ sp00pa02.pdf $>$.

Pacini C., Giesen G., Vazzana C., Wossink A. 2002a. Sustainability of organic, integrated and conventional farming systems in Tuscany. In: Proceedings $13^{\text {th }}$ IFMA Congress of Farm Management. Feed the World Please the Consumer - Maintain the Environment, July 7-12, Papendal Conference Center, Arnhem, The Netherlands.

Pacini C., Lazzerini G., Giesen G., Vazzana C., Wossink A., Huirne R. 2002b. An operational system for measuring sustainability of organic, integrated and conventional farming systems. In: Cristovão A., Omodei Zorini L. (eds.): Farming and Rural systems. Research and Extension. Local Identities and Globalisation. 
Proceedings Fifth IFSA European Symposium, April 8-11, Florence, Italy.

Pacini C. 2003a. An environmental-economic framework to support multi-objective policy-making. A farming systems approach implemented for Tuscany. $\mathrm{PhD}$ thesis Wageningen University, Wageningen, The Netherlands, 173 p. Avaialable at <http://www.library.wur.nl/ wda/dissertations/dis3395.pdf $>$.

Pacini C., Wossink A., Giesen G., Vazzana C., Huirne R. 2003 b. Evaluation of sustainability of organic, integrated and conventional farming systems: a farm and field-scale analysis. Agriculture, Ecosystems and Environment, 95:273-288.

Pacini C., Giannini T. 2004a. La certificazione ambientale in agricoltura. Primo tentativo in Toscana di una norma internazionale. Toscana. L'Uomo, l'Ambiente, n. ottobre/dicembre.

Pacini C., Giesen G., Wossink A., Omodei-Zorini L., Huirne R. 2004b. The EU's Agenda 2000 reform and the sustainability of organic farming in Tuscany: ecological-economic modelling at field and farm level. Agricultural Systems, 80:171-197.

Pacini C., Wossink A., Giesen G., Huirne R. 2004c. Ecological-economic modelling to support multi-objective policy making: a farming systems approach implemented for Tuscany. Agriculture, Ecosystems and Environment, 102:349-364.

Pacini C., Vazzana C., Lazzerini G. 2005. In: Polidori R. et al.: TRENO - Tradurre le risorse endogene delle aree rurali in nuova occupazione. Rapporto di ricerca. Paragrafo 3.3.4 come autore unico; paragrafi 2.3 ; 2.3.1; 2.3.2; 2.3.3; 2.3.4 con Vazzana C.; paragrafi 3.1.3; 3.2 .4 con Lazzerini. G. Fabbri Editore, Perugina, Italia, 247 p.

Pacini C., Righi E., Baijukya F., Bitchibaly K., Kaizzi K.C., Katwijukye A.K., Mapfumo P., Mugendi D., Mwale M., Mwijage A., Nwaga D., Van den Burgh J., Yeboah E. 2006. Generic typologies for categorizing and describing household diversity and livelihood strategies. Sixth EU Framework Programme for Research and Technological Development, Afrianuances Project, Deliverable 6.2.1, Working Document 7.

Pacini G.C., Mwijage A., Tittonell P., Groot J.C.J., Rufino M.C., Van Wijk M.T., De Ridder N., Giller K.E. 2009. Diverging perspectives in the identification of smallholder farmers' objectives and weights for the design of sustainable development strategies of farm livelihood systems (in preparation).

Paracchini M.L., Pacini C., Calvo S., Vogt J. 2008. Weighting and aggregation of indicators for sustainability impact assessment in the IP SENSOR context. In: Helming K., Tabbush P., Perez Soba M. (eds.): Sustainability Impact Assessment of land use policies, 349-372. Springer, Berlin, Germany.

Paracchini M.L., Pacini G.C., Jones M.L.M., Pérez-Soba M. 2009. An aggregation framework to link indicators associated with multifunctional land use to the stakeholder evaluation of policy options. Accepted for publication by Ecological Indicators.

Pileri P. 1992. Interpretare l'ambiente - Gli indicatori di sostenibilità per il governo del territorio. Alinea Editrice, Firenze, Italy.

Righi E., Pacini C., Dogliotti S., Aguerre V., Rossing W. 2009. Farm typology identification by multi-variate analysis as a method to scale-up results of integrated impact assessment analysis. Conference AgSAP, Integrated Assessment of Agriculture and Sustainable Development, 10-12 March, Egmond Aan Zee, The Netherlands.

Rossi R., Nota D. 2000. Nature and landscape production potentials of organic types of agriculture: a check of evaluation criteria and parameters in two Tuscan farm-landscapes. Agriculture, Ecosystems and Environment, 77, 1-2:53-64.

SARD 1991. Elements for strategies and agenda for action (draft proposal). FAO and Ministry of Agriculture, Nature Management and Fishery of the Netherlands, Rome, Italy, 43 p.

Sartori G. 1984. Guidelines for Concept Analysis. In: Social Science Concepts: A systematic analysis. Sage Publications, Beverly Hills, California, USA.

Smith A.J., Dumanski J. 1994. FESLM: An International Framework for Evaluating Sustainable Land Management. World Soil Resources Report No. 73, FAO, Rome, Italy.

Speelman E.N., López-Ridaura S., Colomer N.A., Astier M., Masera O.R. 2007. Ten years of sustainability evaluation using the MESMIS framework: Lessons learned from its application in 28 Latin American case studies. International Journal of Sustainable Development and World Ecology, 14:345-361.

Stern D. 1997. The capital theory approach to sustainability: a critical appraisal. Journal of Economic Issues, 31, 1:145-173.

Trevisan M., Errera G., Capri E., Padovani L., Del Re A.A.M. 1999. Environmental Potential Risk Indicator for Pesticides. In: Reus J., Leendertse P., Bockstaller C., Fomsgaard I., Gutsche V., Lewis K., Nilsson C., Pussemeier L., Trevisan M., van der Werf H., Alfarroba F., Blümel S., Isart J., McGrath D., Seppälä T. (eds.): Comparing Environmental Risk Indicators for Pesticides - Results of the European CAPER Project. Center for Agriculture and Environment, Utrecht, The Netherlands.

Van der Werf H.M.G., Petit J. 2002. Evaluation of the environmental impact of agriculture at the farm level: a comparison and analysis of 12 indicator-based methods. Agriculture, Ecosystems and Environment, 93, 1-3:131-145.

Van Mansvelt J.D., Lubbe van der M.J. 1999. Checklist for sustainable landscape management. Elsevier Science B.V., Amsterdam, The Netherlands.

Vazzana C., Raso E., Pieri S. 1997. Una nuova metodologia europea per la progettazione e gestione di agroecosistemi integrati ed ecologici: applicazione in un'area agricola Toscana. Rivista di Agronomia, 31, 2:423-440.

Vazzana C., Lazzerini G. 2007. Effetti dei miglioramenti ambientali e della tecnica colturale su specie selvatiche e habitat. In: Valorizzazione agro-forestale e faunistica 
dei territori di collina e montagna, 221-240. Istituto Nazionale per la fauna Selvatica, Ministero delle Politiche Agricole Alimentari e Forestali, Bologna.

Vazzana C., Raso E., Migliorini P. 2008. Sustainability evaluation of long term organic farm systems. ISOFAR International Scientific Conference, IFOAM World Congress, 2008, Modena.
Vereijken P. 1999. Manual for prototyping integrated and ecological arable farming systems (I/EAFS) in interaction with pilot farms. AB-DLO, Wageningen, NL.

Weersink A., Jeffrey S., Pannell D. 2002. Farm-level modeling for bigger issues. Review of Agricultural Economics, 24, 1:123-140. 